\title{
TO SPEAK AS A JUDGE: DIFFERENCE, VOICE AND POWER BY SANDRA BERNS
}

\author{
Sandra Petersson ${ }^{*}$
}

Sandra Berns To Speak as Judge: Difference, Voice and Power (Ashgate, Aldershot (UK), 1999) $241+$ viii pages, $\$ 180$.

To Speak as a Judge: Difference, Voice and Power is the twenty-fifth title in the Applied Legal Philosophy Series (Tom Campbell, General Editor). Previous contributors to the series include Christine Bell, Neil MacCormick, Pamela Gray, Robert Summers, Catherine Lowy, and William Conklin. This latest title is the work of Professor Sandra Berns, recently Dean of Law, Griffith University, Queensland.

The book is a postmodern feminist exploration of the nature of adjudication. As Professor Berns, explains, her interest is: ${ }^{1}$

... not simply in the nature of law, but in the speech of judges, in all those different things judges do with words that go to make up the performance we call judgment. Judgment let us say as theatre. And by performance I mean total performance, beginning to end, from the moment the case appears on the docket to the moment at which judgment is final and cannot be called back. I am interested in questions of voice, of presence and absence, of the possibility of the feminine in or as judgment.

* Lecturer in Law, Victoria University of Wellington.

1 Sandra Berns To Speak as Judge: Difference, Voice and Power (Ashgate, Aldershot (UK), 1999) 1. Chapters one, three, four and five are based on previously published work: see Sandra Berns "Constituting a Nation: Adjudication as Constitutive Rhetoric" in Interpreting Constitutions (Federation Press, Sydney, 1996) 84-120. 
The book offers an observational account of judging focussed on the level of superior courts. $^{2}$ It is a time-honoured, if sometimes frustrating, convention that any analysis of the judicial office must rely on observational study. The positions of judge and law professor are rarely held concurrently. ${ }^{3}$ Most academics, therefore, have no personal experience within the role of judge. Moreover, judges are constrained in the public comments they may make regarding their judicial role. The general statements allowed to judges rarely answer the specific questions academics want to raise. ${ }^{4}$

As a general exploration of the process of adjudication, this book covers many themes including the creation and expropriation of legal stories, the rhetoric of judgment, the violence of judicial decision making, and polyvocality. However, the central theme that appears throughout the book is the position of women judges and of what it means "to be a woman and to speak as a judge, and to speak as a judge and as a woman in a world in which woman remains a negation". ${ }^{5}$ This analysis is based on the premise that the role of judge is a traditionally male role; our understanding of who a judge is and how a judge acts carries embedded male norms, if only for the simple reason that until the early 20th century all judges were men. The book is concerned both with what happens to the role of a judge when it is assumed by a woman and with what happens to a woman who assumes the role of a judge. As Professor Berns explains: ${ }^{6}$

2 While the author is critical of the traditional academic focus on written appellate decisions (Berns, above $n 1,4-5)$, her analysis remains centred on the work of superior rather than lower courts. This focus is clear in the case examples discussed. It is also apparent in the discussion of the separate roles served by the oral and written forms of judgment in a single case and in the perception that women judges are still exceedingly rare; these factors are more indicative of superior courts than lower courts.

3 Chief Judge Richard Posner of the United States Court of Appeals for the Seventh Circuit is a notable exception in his continued appointment at the University of Chicago Law School. For a further discussion of the generally separate roles of judges and law professors see Justice Ruth Bader Ginsburg "On the Interdependence of Law Schools and Law Courts" (1997) 83 Virginia L Rev 829.

4 For example, judges may not comment on a specific decision making process outside of the judgment handed down. For further examples of the constraints placed on the judiciary see generally the Canadian Judicial Council Ethical Principles for Judges (Ottawa, 1998).

5 Berns, above $\mathrm{n} 1,3$.

6 Berns, above n 1, 3-4. For the most part, the author's position as an observer is reinforced by the fact that she refers to judges in the third person. However, on occasion, as in this example, she moves confusingly from a position of observation to one of experience by adopting the first person. Similarly on page 18, she states: "I speak judgment in an open court, in public, as 'judge' B and here I am wigged and gowned B depersonalised, deprived of identity". 
If to speak as a judge can be, at times, to speak in a voice one finds repugnant, and if at some point the judge finds that she must deny the feminine if she is to speak as a judge, how does she (do I) speak at all if by our speech we have accepted that we exist, at best, as the never-to-be of justice? Can one, perhaps, write oneself out of existence with one's own words?

Postmodern theory recognises that any observation will be coloured by the subjectivity of the observer. I see difficulty with this account of judging because it does not reflect my observations, particularly regarding women judges. While it is possible to write women judges into non-existence in theory, it is impossible to deny their existence in reality. To suggest that women judges have a marginal existence relative to men judges compromises the integrity of the legal system by deriving authority from the personal identity of the office-holder rather than from the judicial office itself. Moreover, the suggestion that women cannot speak with authority as women and judges runs dangerously close to the historical argument that women have no authority to speak as judges at all. ${ }^{7}$

The image of the woman judge that appears throughout the book is that of an individual facing a constant struggle to retain an identity of her own. For example, the author argues that women's identities as judges are constantly concealed by the conventions of judging, that is by such factors as judicial dress, the abbreviation J, and by written judgments not being (physically) heard in a male or female voice, such that: ${ }^{8}$

[W]ithin the frame of reference of the law report the judge becomes (except to those who are aware of the reality of the matter) simply the judge.... Like the theatrical trappings of wig and gown, the conventions of judgment obliterate the stigmata of race and gender.

However, such conventions are easily changed because the position of judge is a position of power. For instance, take the given example of judicial dress. Many women judges have adopted their own model of judicial dress, often by choice as in the preference for a collar in place of bands or for trousers in place of a skirt, but on occasion by necessity, as in the selection of judicial maternity wear. Having been fixed since the time of Queen Anne, judicial dress was a male convention. However, that fact also allowed

women

7 See for example, $R v$ Cyr [1917] 3 WWR 849 (Alta SCAD) in which counsel argued that the trial decision was invalid because the judge was a woman.

8 Berns, above n 1, 203. See generally Chapter Nine "To Speak as Judge/Woman: A Different Voice?". 
judges to reject it and create their own form. ${ }^{9}$ Similarly, women judges frequently sign their full names to written judgments. While some law reports maintain the format of Surname J, most follow the judge's own preferred "by-line". Court specific reporters and web sites also list judges' full names, making it a relatively simple matter to determine which judges are men and which are women when this difference is relevant. ${ }^{10}$ While to date, the prevalence of written judgments has perpetuated an ungendered (and disembodied) judicial voice, increased broadcasting of judicial proceedings may increase the familiarity of gendered voices. Thus, the conventions that may previously have concealed the "stigmata" of gender are of decreasing relevance.

In addition to such external challenges to identity, the book portrays women judges as facing an internal identity crisis in having to continually balance acting as a judge against acting as a woman in instances where the two are in conflict. In adopting this position the book goes beyond an observer's account to speculate on a subjective state. This is a tenuous position but one that would be strengthened by reference to the experience of women judges. While women judges have commented on being women judges they have not described this

9 For example, compare the judicial dress of Justices Sandra Day O'Connor and Ruth Bader Ginsburg to that of the men judges on the United States Supreme Court: $<$ http://supct.law.cornell.edu/supct/justices/fullcourt.html>. Their judicial dress is also distinct from each other's suggesting that each has adopted her own convention. The Chief Justice of Canada, The Right Honorable Beverley McLachlin and Justices Claire L'Heureux-Dube, Beverley McLachlin and Louise Arbour of the Supreme Court of Canada have also adopted their own style of judicial dress for ordinary hearings. Arguably, the fur-trimmed red velvet ceremonial robes worn by Supreme Court of Canada judges are not particularly masculine.

10 Unfortunately Professor Berns has herself been complicit in erasing identity of women judges. Of the judgments directly cited in the book, there are only two examples by women judges, both of whom are consigned to the "never-to-be of justice". In discussing the joint judgment of Justices Deane and Gaudron in Mabo v Queensland (No 2) (1991) 175 CLR 1, the plural pronoun "they" hides the fact that Justice Gaudron is a woman: Berns, above n 1, 67. Additionally, McLachlin J is criticised for the fiduciary model "he adopts as his paradigm" in Norberg $v$ Wynrib (1992) 92 DLR (4th) 449 (SCC): above n 1, 122. Justice Beverley McLachlin was the third woman appointed to the Supreme Court of Canada and the first woman to become Chief Justice of Canada. 
internal crisis. ${ }^{11}$ It is of course arguable whether a woman judge could or would comment on the potential for woman / judge conflict; it is easy to imagine how such comments would be used as grounds to disqualify women judges for bias in particular cases, in favour of more neutral men judges. Alternatively, the position would be strengthened by reference to empirical studies that attempt to answer, from an observer's perspective, whether women judges do in fact speak in a "different voice" relative to men judges. ${ }^{12}$ If this is the case, it would seem to indicate that the internal crisis has been resolved to identify as woman rather than judge. Conversely, if women judges do not speak in a different voice, the question becomes to what degree the internal crisis has been resolved to identify as judge rather than woman or, possibly, to identify as man rather than judge or woman. If, however, the results of different voice studies are inconsistent or conflicting, this would support the ongoing struggle for identity suggested in the book.

To Speak as a Judge suggests that further and ongoing reflection on the position and role of women judges is required. To this I would add that a better understanding of what it means to be a woman judge will also lead to a better understanding of what it

11 Ironically, where women judges have noted an identity crisis it lies in being mistaken for other women judges: see Justice Ruth Bader Ginsburg "Report of the Special Committee on Gender to the DC Circuit Task Force on Gender, Race and Ethnic Bias" (Foreword) (1996) 84 Georgetown LJ 1651, 1653. As to whether they decide cases differently than men judges, women judges have frequently quoted Justice Jeanne Coyne of the Minnesota Supreme Court who said "a wise old man and a wise old woman reach the same conclusion": see Justice Sandra Day O'Connor "Portia's Progress" (1991) 66 New York University L Rev 1546, 1558; and Justice Ruth Bader Ginsburg , above, 1654.

While Professor Berns makes almost no reference to articles or cases by women judges, it is worthwhile to consider Justice Claire L'Heureux-Dube "Making a Difference: the Pursuit of a Compassionate Justice" (1997) 31 University of British Columbia L Rev 1; Justice Ruth Bader Ginsburg "Judicial Independence" (1998) 72 Australian LJ 611; and Justice Ruth Bader Ginsburg "Reflections on Way Paving Jewish Justices and Jewish Women" (1998) 14 Tuoro L Rev 283. See also Elaine Martin's survey of women judges and their role: "The Representative Role of Women Judges" (1993) 77 Judicature 166.

12 See generally: Regina Graycar "The Gender of Judgments: An Introduction" in Margaret Thornton (ed) Public and Private: Feminist Legal Debates (Oxford University Press, Melbourne, 1995) 262; Peter McCormick and Twyla Job "Do Women Judges Make a Difference? An Analysis by Appeal Court Data" (1993) 8 Canadian J of L and Society 135; Joan Brockman "A Difference Without a Distinction" (1993) 8 Canadian J of L and Society 149; Peter McCormick "Hypotheses, Statistics and Women Judges: A Reply" (1993) 8 Canadian J of L and Society 165; Sue Davis, Susan Haire, and Donald R Songer "Voting Behaviour and Gender on the United States Courts of Appeals" (1993) 77 Judicature 129; Sue Davis "The Voice of Sandra Day O'Connor" (1993) 77 Judicature 134; David W Allen and Diane E Wall "Role Orientations and Women Supreme Court Justices" (1993) 77 Judicature 156; "Different Voices, Different Choices? The Impact of More Women Lawyers and Judges on the Justice System" (panel discussion) (1990) 74 Judicature 138. For effects beyond gender see Audrey Kobayashi "Do Minority Women Judges Make a Difference?" (1998) 10 Canadian J of Women and the L 199. 
means to be a man judge. The very expressions "woman judge" and "man judge" reinforce the need for such inquiry. It is common to speak of a "woman judge". However, by its connotation and dissonance, the expression "man judge" prompts us to modify our terminology, to speak instead of a "male judge" and to rewrite "woman judge" as "female judge". This highlights the inherent maleness of the word "judge". Yet we must also recall that the role of judge is an artificial character created to serve the public function of law. We require judges to act with humanity and yet we would set them apart from other human beings. ${ }^{13}$ By better understanding the concept of judge we may better understand to what degree we have constructed a role that does not reflect the reality of our society, a role that has been gendered, raced, and classed by history. As Justice Claire L'HeureuxDube has urged, what is important is: ${ }^{14}$

to hear and act upon what women judges and many others have to say about their reality when faced with the law. This is not an exercise in abstraction and principle alone, but an immersion of ourselves in the details of the everyday lives [of people of all genders and cultures].

13 Consider, for example, the Canadian Judicial Council's Commentary on "Integrity" in Ethical Principles for Judges, above n 4, 15:

A judge's conduct, both in and out of court, is bound to be the subject of public scrutiny and comment. Judges must therefore accept some restrictions on their activities - even activities that would not elicit adverse notice if carried out by other members of the community. Judges need to strike a delicate balance between the requirements of judicial office and the legitimate demands of the judge's personal life, development and family.

14 Justice Claire L'Heureux-Dube, above n 11, 15. The original quote closed with a reference to an earlier passage in the article where Justice L'Heureux-Dube referred to a comment by Mari Matsuda. 